VAK 323(4/9)

ББК $66.3(4 / 8)$

DOI 10.22394/1682-2358-2018-6-30-35

R.M. Radman Madged, post-graduate student of the Humanities and Social Sciences Department, Tula State University

\section{THE MAIN TRENDS OF TRANSFORMATION OF THE POLITICAL SYSTEM OF THE REPUBLIC OF YEMEN}

The regular changes of political power in the Republic of Yemen are considered. Prospects of transformation of the state political system, as well as the main opportunities and prerequisites are analyzed Proposals on de-escalation of the conflict in the Republic of Yemen are made.

Key words and word-combinations: coup, revolution, political system, President, Yemen, Middle East.
P.М. Радман Маджед, аспирант факультета гуманитарньх и сочиальньгх наук Тульского государственного университета (email: radmanmajed611@gmail.com)

\section{ОСНОВНЫЕ ТЕНАЕНЦИИ ТРАНСФОРМАЦИИ ПОАИТИЧЕСКОЙ СИСТЕМЫ РЕСПУБАИКИ ЙЕМЕН}

Аннотация. Рассматривается механизм регулярной смены политической власти в Йеменской Республике. Анализируются перспективы трансформации политической системы государства, основные возможности и предпосылки. Делаются предложения по деэскалации конфликта в Йемене.

Ключевые слова и словосочетания: переворот, революция, политическая система, президент, Йемен, Ближний Восток.

B Аасть в современном Йемене меняется достаточно регулярно, и обычно не мирным способом. Череда переворотов и револющий сопровожАает историю этого государства. Аия осмысления нынешнего состояния Йемена и происходящих в нем процессов необходимо обратиться к важнейшим вехам в истории страны. Противоречия в Йемене усилили события «арабской весны» (2010-2011), которая обострила и без того существенные конфликты в госуАарстве. Сепаратистские настроения на юге страны, активная деятельность АКАП (отдемение движения «Аль-Каида» на Аравий- 
ском полуострове), в результате которой данной группировке удалось занять несколько населенных пунктов в Йемене, а также не до конца урегулированные противоречия с хуситами в условиях массовых беспорядков, спровоџированных «арабской весной», привели к дестабилизаџии внутреннего состояния Йеменской Республики в 2011 г.

Это проявияось в цеелом ряде тенденций, связанных с ослаблением центральной власти в Йемене: появились течения, настроенные против правительства, и от власти был отстранен президент страны Али Абдамла Салех [1]. На досрочных президентских выборах в 2012 г. победил единственный кандидат - АбА-Раббу Мансур Хади. Несмотря на фактически бескровный перехоА государственной вмасти, что совсем не характерно для народных волнений, вызванных «арабской весной», новая йеменская власть была не способна разрешить рял острых соџиальных и политических противоречий, что стало оАним из главных факторов эскалации вооруженного противостояния, начавшегося в 2014 г. [2].

Самым ярким проявлением неспособности государственной власти решить змободневные вопросы обшественной жизни стала военная реформа, проведенная при президенте Йеменской Республики Мансуре Хади, в итоге которой значительно снизилась боеспособность йеменской армии и усилилось значение нерегулярных военизированных формирований, находившихся под управлением разнообразных внутрийеменских сил. Стоит упомянуть попытку неудачной административной реформы, в результате которой произошло резкое обострение отношений межАу внутренними политическими сиками Йемена [1] .

В июле 2013 г., с возвратом к управлению Йеменской Республикой политических сил, смещенных от власти в Египте в 2011 г., в стране был сформирован прецедент «внутренней контрреволюџии», который из единичного случая мог перейти в правимо. В проџессе поэтапного краха авторитарных режимов (Египет, Тунис, Йемен и др.) арабское общество показало пристрастие к «принципу домино». Выходя с акџиями протеста на улиџы своих городов, граждане того или иного государства постоянно оглядывались на происходящее у соседей. Колоритным примером такой «преемственности револющий» и стал современный Йемен. Например, в начаме 2012 г., когда бывший мидер государства Али АбАамла Салех уже ушел с собственного поста, йеменская оппозиџия мотивировала собственный отказ уходить с уциџ тем, что освободившееся место могут занять исламисты, как это бымо на тот момент в Египте.

Такие опасения были обоснованы: с начала 2012 г. политическая власть в Йемене понемногу переходила к семейству аль-Ахмаров, а именно к сыновьям умершего в 2007 г. мидера племенной конфедерации Хашид Абдамлы альАхмара. Его главными союзниками стали исламистская политическая партия «аль-Ислах» (Йеменское объединение за реформы) и йеменские «Братья-мусульмане», которые поднялись на волне успеха собственных идеологических вдохновителей в Египте. Негласным союзником аль-Ахмаров стал и временный президент государства АбА Раббу Мансур Хади, отличавшийся отсутствием политических амбиџий. Но удача сопровожАала семейство мишь до того вре- 
мени, пока «Братья-мусульмане» находимось у власти в Египте; низвержение Мухаммеда Мурси и следующая межарабская изоляџия ассоџиации и ее заграничных ячеек сильно надмомили позиции временного йеменского правительства. Собственно, Йемену было предназначено стать вторым посме Египта государством, где вышедший на поверхность в ходе «арабской весны» протестный потенциал был достаточным А^я реализации «Авойной» революции.

После неудачи Всеобщего нащионального диалога (ВНА) в начале 2014 г. главные политические силы Йемена сконџентрировались вокруг Авух противостоящих магерей: Всеобщего народного конгресса (BHK), который возглавлял смещенный в процессе «арабской весны» А^и Самех, и кмана аль-Ахмаров, управцяемого Садыком аль-Ахмаром. За прошедшие годы эти две силы занями противоположные политические полюса и начали искать союзников среди Аругих политических акторов Йемена.

25 февраля 2012 г., когда в результате проведения выборов президента Йеменской Республики к власти пришел Мансур Хади, была миквидирована «нарезка» военных округов, традиционная дия современного Йемена. В результате фактически полностью исчезла национальная армия и была распущена Респуб̆ликанская гвардия, которой управмял сын Али Абдамлы Салеха ее преобразовали в резервные войска. Военные реформы Мансура Хади привеми к тому, что в Йемене вокруг каждой из политических сил сложилась собственная военизированная группировка. Интересно, что при подобном расклаАе самой боеспособной стала армия хуситов, которую назваци в честь убитого мидера Хусейна БаАр аА-Аина аль-Хуси. В последние годы она одержала целый ряА больших военных побеА и распространила влияние на территорию фактически всего северного Йемена.

После 21 сентября 2012 г. аль-Ахмары потерпели полное поражение переА хуситами, их мидеры вынуждены были бежжать из страны. Сегодня максимальный интерес преАставцяет негласный союз ВНК и хуситской оппозиџии, представлявшийся еше пару мет назаА невообразимым. В течение правления экс-президента север Йемена был самым опасным регионом страны. Распри межАу политическим режимом и хуситами были довольно давние, а сам президент в течение собственного правления шесть раз вел борьбу против хуситского Авижения «Ансар Аммах».

В начале 2014 г. эти Аве политические силы оказались по одну сторону баррикаА, выступив обстоятельным противовесом существующей государственной власти в миџе аль-Ахмаров. Военные реформы последнего времени привели к формированию в Йемене собственной военизированной группировки вокруг ^юбой политической силы. Аль-Ахмары в Йемене во многом допустили такие же просчеты, что и движение «Братья-мусульмане» в Египте.

Очередной виток эскалаџии противоречий возник в 2014 г. в связи с новым обострением в отношениях хуситов и центральной государственной власти. В январе 2015 г. хуситы заняли столицу Йемена Сана, и президент АбА-Раббу Мансур Хади вынужден был уйти с поста. Аанная ситуация опредемика потребность основания нового органа государственной вмасти, необходи- 
мого дмя формирования переходного Наџионального совета. Таким органом становится Революционный комитет, который возглавил Мухаммед Али альХуси. Но Мансуру Хади удалось сбежать из заключения в Сане, и он собрал своих союзников в Адене и заявил о собственном намерении вновь возглавить Йеменскую Республику. ОАнако через некоторое время Мансуру Хади пришиось уехать в Саудовскую Аравию, и именно оттуда он стал руководить своими сторонниками.

Еще одна иниџиатива аль-Ахмаров восстановима против себя и ВНК, оспаривавшего предможение на десять мет запретить выдвижение на пост президента мицам, раньше занимавшим военные должности. Несомненно, что это нововведенное требование касалось АхмеА Салеха - сына прежнего президента, поэтому аль-Ахмары вместе с Авижением «Братья-мусульмане» вступили в конфликт со всеми ведущими политическими силами государства. Проблема Юга, где не утихают симьные демонстрации под мозунгами отделения региона в границах бывшей НАРЙ, и сегодня не решена.

Власть в Сане, все больше ассоциируюшаяся с исламистами, не устраивает южан, которые еше помнят события 1994 г. Тогда Север стал проводить гегемонистскую политику по отношению к Югу, основывавшуюся на идеях Ауховных мидеров общественного Авижения «амь-Ислах», преимущественно амь-Аайлани и аль-Зиндани, обнародовавших Ажихад «безбожникам» с Юга. Не сформировались устойчивые политические отношения у аль-Ахмаров и с хуситами. При деятельном содействии движения «аль-Ислах» в Йемене была основана салафитская исламистская группировка «ан-Нусра», которая должна быма противостоять движению «Ансар Аммах».

Сходная тактика уже наблюдалась в прошлом - во второй половине 2000-х годов режим применяли салафитские радикалы в собственных внутриполитических интересах. Связано это было преимущественно с именем генерала А^и Мохсена аль-Ахмара, осуществцявшего прямое руководство шестью военными операциями в Сааде в 2004-2010 гг. и часто использовавшего услуги салафитов в борьбе с хуситами. В Йемене Аль-Ахмары во многом допустили те же ошибки, что и «Братья-мусульмане» в Египте. Наконец, альАхмары стали конфликтовать с Всеобщим народным конгрессом и кично с Али Салехом.

Подтверждением этому явмяются многократные попытки арестовать экспрезидента, предпринимавшиеся временными властями. Именно Али Мохсен, возглавлявший в 2011 г. первую бронетанковую дивизию, был ключевой военной симой, которая примкнула к протестующим в ходе «арабской весны». Самое напряженное противостояние произошио осенью 2011 г. в столичном районе аль-Хасаба между силами, моямьными Али Салеху, и аль-Ахмарами. Складывавшаяся с начала 2012 г. ситуация, при которой власть в Йемене постепенно сосредоточивалась в руках аль-Ахмаров в миџе Авижения «аль-Ислах» и их союзников, представленных «Братьями-мусульманами» и салафитами, поставила их оппонентов по одну сторону баррикад и вынудила пойти на крайние меры. Подлимо масла в огонь и все возрастающее в последние годы влияние А^и Мохсена, вступившего в домжность советника президента Ман- 
сура Хади по военным вопросам и не скрывавшего своих притязаний на пост руководителя страны.

Очевидно, что подобные перспективы категорически не устраивали ни хуситов, ни ВНК, ни южан. Это предопределило "революџию 21 сентября», после которой аль-Ахмары были вынуждены покинуть страну, в то время как Авижение «Ансар Аммах», проводя политику союзов с йеменскими пмеменами и членами ВНК, по сути установимо контроль наА северным Йеменом. КАючевой вопрос, который сегодня стоит на йеменской политической повестке Аня, - будущее юга страны. Хуситы продолжают вести переговоры с сепаратистским Авижением «Аль-Хирак» относительно возможности сосуществования в граниџах одного государства.

Но перспективы единого Йемена пока остаются туманными. Во многом именно этим объясняется тот факт, что АбА Раббу Мансур Хади до сих пор занимает пост временного президента страны, и последние перемены во власти его не коснулись. Велика вероятность, что мишение Мансура Хади президентского кресла вынудит его бежать на юг, откуда он родом, что способно только усилить сепаратистские настроения в ААене. Это, в свою очередь, может бросить тень на позиции хуситов, которых в Аанном скучае обвинят в распаде страны.

2015 г. ознаменовался полномасштабным вторжением арабской коалищии под руководством Саудовской Аравии в Йемен. В войне против Йемена, кроме саудитов, приняли участие Объединенные Арабские Эмираты, Бахрейн, Египет, Марокко, Иордания, Кувейт и Пакистан. Последний мишь формально присоединияся к антийеменской коалиции, но никакого реального участия в конфликте не принимает. Основную тяжесть войны несут на себе Саудовская Аравия, ОАЭ и Бахрейн.

В стране в настоящее время существует крупное противостояние. На развитие конфцикта оказывает значимое влияние ряд внутренних сиц, оАной из них являются правительственные силы во главе с президентом АбА Раббу Мансуром Хади. Помимо президентских сил в вооруженном конфликте активно участвует движение «Аль-Хирак», которое распространилось в южных провинциях Йемена, а также движение шиитов-зейдитов (хуситов) «Ансар Амлах», распространившееся в северных регионах страны при подлержке военных частей, которые по-прежнему подАерживают Салеха, несмотря на его отстранение. Активно участвует в конфликте АКАП [3] и ряд племенных объединений, самые известные из которых ХашиА, Бакиль, Мадхиж [4]. Цели, которые преследует каждая из сторон в Аанном конфликте, часто разнонаправлены. Мансур Хади и его сторонники ориентированы на восстановление государственной власти во всех регионах, оказавшихся в руках разнообразных вражАующих группировок [5]. Авижение «Аль-Хирак» направмяет свою деятельность на возрождение НАРЙ в рамках 1990 г., но сегоАня у группировки нет необходимых ресурсов для осушествления назначенных задач. Цель АКАП Аравийской региональной организаџии Авижения «Аль-КаиАа» - создание исламского государства, основанного на нормах шариата [6] . Авижение «Ансар Алмах» направляет свою деятельность на свержение политического режима

34 Bulletin of the Volga Region Institute of Administration • 2018. Vol. 18. № 6 
Мансура Хади и федерализацию Йемена, что частично сближает их взгляды с Авижением «Аль-Хирак».

В настояшее время Революционный комитет преобразован в Верховный политический совет Йемена (ВПС), Аатой создания которого стало 6 августа 2016 г. Возглавлял до апреля 2018 г. ВПС Салех Али аль-СамаА, который фактически являлся высшим должностным Аиџом государства. Сегодня ВПС объединяет и сторонников хуситов, и представителей ряда провинций, нахоАяшихся на юге. На юге Йемена получило также широкое распространение Авижение «Аль-Хирак», выступающее за предоставление более широкой автономии провинџиям, некогАа входившим в состав НАРЙ [7] .

Аальнейшая эскалация конфликта способна привести к разрастанию масштабов гуманитарной катастрофы, обострению террористической угрозы, так как позиции АКАП в регионе становятся все более прочными. Наиболее эффективным способом урегулирования конфликта могла бы стать активизаџия переговорного проџесса, но в силу крайнего отличия цемей, преследуемых различными сторонами конфликта, этот сџенарий остается маловероятным [8]. Но факт того, что конфцикт без особых успехов Амя каждой из сторон формируется уже много мет, а также присутствие общего врага в миџе АКАП могут содействовать понижению градуса напряженности противостояния и поэтапному переходу к переговорному процессу. Значимым шагом в разрешении конфликта может быть предоставление большей свободы деятельности гуманитарным организаџиям, функционирующим поА эгидой ООН. Самым допустимым исходом конфликта в Йемене может быть федерализация страны с предоставлением обширной автономии некоторым ее субъектам [9].

\section{Библиографический список}

1. Исаев Л.М., Шишкина А.Р. Сирия и Йемен: Неоконченные революции. М., 2012.

2. Попов Н.Г. Причины возникновения и перспективы развития вооруженного конфликта в Йемене (2014-2017 гг.) // Научное сообщество студентов XXI столетия. Общественные науки: сборник статей по материалам LI международной студенческой научно-практической конференции. № 3 (50). URL: https://sibac.info/archive/social/3(50).pdf

3. Джихад в тени «Исламского государства» // Lenta.ru. URL: https://lenta.ru/articles/2016/03/28/terrorworldwide/

4. Starving Yemenis resort to eating rubbish crisis // Aljazeera. URL: http://www.aljazeera.com/ indepth/features/2017/01/starving-yemenis-resor...

5. Косач Г.Г. Эволюция внешней политики Саудовской Аравии после «арабской весны» // Cyberleninka. URL: http://cyberleninka.ru/article/n/evolyutsiya-vneshney-politiki-saudovsko

6. Исаков А.C. Вооруженный конфликт в Йемене: Анализ интересов сторон и перспективы разрешения // Электронный научный архив УрФУ. URL: http://elar.urfu.ru/ bitstream/10995/32328/1/klo_2015_182.pdf

7. Кризис в Йемене: перспективы для российской дипломатии? // ussiancouncil.ru/analyticsand-comments/analytics/krizis-v-yemene-perspektivy-dlya-rossiyskoy-diplomatii/

8. Полонский И. Война в Йемене: стоит ли России ввязываться в конфликт? URL: https:// topwar.ru/130155-voyna-v-yemene-stoit-li-rossii-vvyazyvatsya-v-konflikt.html

9. Федорченко A.B. Йеменская Республика: преодолевая сепаратистские тенденции // Cyberleninka. URL: http://cyberleninka.ru/article/n/yemenskaya-respublika-preodolevaya-sepa... 